\title{
Erratum to: In vitro minimal growth storage of Saccharum spp. hybrid (genotype 88H0019) at two stages of direct somatic embryogenic regeneration
}

\author{
M. P. Watt $\cdot$ M. Banasiak $\cdot$ D. Reddy $\cdot$ \\ E. H. Albertse $\cdot$ S. J. Snyman
}

Published online: 12 November 2009

(C) Springer Science+Business Media B.V. 2009

Erratum to: Plant Cell Tiss Organ Cult (2009) 96:263-271

DOI 10.1007/s11240-008-9483-9

It has recently come to our attention that there was a mistake in our calculations of polymorphic rates: those given as 0.007 and 0.005 should be 0.7 and 0.5 , respectively. The following parts of the original publication are concerned:

1. Abstract, page 263, second last sentence in abstract.

2. Table 1, page 268, in the last line of the Table.
3. Page 268 in text under heading 'Phenotypic assessment and genetic integrity,' 2nd paragraph.

These corrected results do not change the outcomes of the study. We apologize for any inconvenience.

The online version of the original article can be found under doi:10.1007/s11240-008-9483-9.

M. P. Watt · M. Banasiak · D. Reddy · S. J. Snyman

School of Biological and Conservation Sciences, University

of KwaZulu-Natal, Private Bag X54001, Durban 4000,

South Africa

E. H. Albertse · S. J. Snyman ( ()

South African Sugarcane Research Institute (SASRI),

Private Bag X02, Mount Edgecombe 4300, South Africa

e-mail: Sandy.Snyman@sugar.org.za 